\title{
Rare cause of non-immune hemolytic anemia in end-stage liver disease
}

\author{
Maheep Singh Sangha*1, Aakash Aggarwal ${ }^{2}$, Japmehr Sandhu ${ }^{3}$ \\ ${ }^{1}$ The Warren Alpert Medical School of Brown University, Providence, United States \\ ${ }^{2}$ Northwell Health/Lenox Hill Hospital, New York, United States \\ ${ }^{3}$ Government Medical College, Amritsar, Punjab, India
}

Received: May 13, 2020

DOI: $10.5430 /$ crim.v7n2p7
Accepted: May 27, 2020

Online Published: June 11, 2020

\begin{abstract}
Spur cells are reportedly linked to advanced end-stage liver diseases and may lead to accelerated hemolysis. In this case report, we discuss one of these rare instances when a 45-year-old female with decompensated cirrhosis was admitted for severe anemia. Extensive workup revealed non-immune hemolysis secondary to spur cell formation. Orthotopic liver transplantation remains the only treatment of choice for reversal of spur cell anemia. Alternatively, multidrug therapy has also been explored, including usage of bile acid sequestrants; however, success is rare.
\end{abstract}

Key Words: Spur Cell Anemia, Acanthocytes, Orthotopic Liver Transplantation, SCA, Zieve Syndrome

\section{INTRODUCTION}

Cirrhotic patients often have anemia due to multiple overlapping etiologies like blood loss, bone marrow suppression, splenic sequestration due to portal hypertension, vitamin B12 and folate deficiency, and infrequently due to hemolysis. Hypersplenism and acquired alterations in the red blood cell membrane (e.g., target cells, acanthocytes, echinocytes, stomatocytes) are the two most common causes of hemolysis in patients with cirrhosis. ${ }^{[1]}$ Spur cells are the severe form of acanthocytes that have many irregular thorn-like projections formed because of a decreased ratio of phospholipids to cholesterol in red blood cell membranes and have been furthermore altered by an enlarged spleen. ${ }^{[2,3]}$ Hemolysis due to a consequence of changes to red blood cell membranes leading to spur cell formation carries an abysmal prognosis as it generally reflects end-stage liver disease. ${ }^{[4-6]}$

\section{Case presentation}

A 45-year-old female with a medical history significant for alcoholic cirrhosis presented to the hospital complaining of dyspnea, fatigue, and jaundice. Work-up revealed severe anemia with a hemoglobin of 4.3. The patient mentioned that she quit drinking alcohol eight months ago and denied any bleeding episode. The patient had evidence of hemolysis considering elevated total and direct bilirubin of 19.6 and 6.4, respectively, high reticulocyte count of 18.3, high lactate dehydrogenase of 851 , and an undetectable level of haptoglobin. The patient had mildly elevated liver function tests with an elevated INR of 2.5, and a negative disseminated intravascular coagulation (DIC) panel and Coombs test. Vitamin B12, folic acid, Free T4, and phosphate levels were normal. The patient had a deranged cholesterol panel with low HDL levels of 25. The peripheral smear did not reveal any schistocytes, spherocytes, or any other evidence States.

*Correspondence: Maheep Singh Sangha; Email: maheepsangha@gmail.com; Address: 1 Regency Plz, Apt 715, Providence, RI - 02903, United 
of autoimmune or microangiopathic hemolytic anemia. However, a large number of acanthocytes were seen on peripheral smear, which was suggestive of spur cell anemia. In our patient, spur cell anemia was secondary to decompensated end-stage liver disease (Child-Pugh C; MELD score 30). Pentoxifylline is known to enhance erythrocyte distensibility hence leading to a reduction in spur cells. The patient was started on folic acid and pentoxifylline, with a plan to start cholestyramine for trial. The patient was treated with blood transfusions as needed for symptomatic anemia and referred to the transplant center for orthotopic liver transplantation. Unfortunately, the patient died within three months before receiving a transplant.

\section{DISCUSSION}

The formation of acanthocytes on peripheral smear can be seen in patients with end-stage liver disease. ${ }^{[1]}$ Alteration in membrane fluidity of red blood cells secondary to an abnormality in the lipid composition of the cell membrane due to underlying cirrhosis and dyslipidemia leads to the formation of acanthocytes. Morphologically, these cells present with irregular thorny projections, which, if slightly rounded, are known as spheroacanthocytes or spur cells. ${ }^{[7]}$ Spur cells can lead to acquired non-immune hemolysis and severe anemia requiring multiple red blood cell transfusions. ${ }^{[8]}$ Hemolysis leads to an accumulation of hemoglobin breakdown products and thus, unconjugated hyperbilirubinemia. Biochemically, this translates into an elevated indirect and total bilirubin lev- els. Patients with spur cell anemia have a median survival of a few months. Spur cell formation has only been reversed by liver transplantation, and there is no other effective therapy. ${ }^{[9]}$ Splenectomy may benefit, but these patients are not good surgical candidates because of underlying decompensated cirrhosis. Early diagnosis of spur cell anemia is imperative to identify candidates eligible for a liver transplant as it resolves after orthotopic liver transplantation. ${ }^{[10]}$ In patients with end-stage liver disease, the Child-Pugh and Model for End-Stage Liver disease (MELD) scores are commonly used to predict prognosis, guiding treatment options, and prioritizing patients for liver transplantation. MELD score is used more frequently than Child-Pugh, given its better prognostic value. However, a significant limitation of the MELD score is the exclusion of signs of portal hypertension like ascites and varices. Advanced liver disease is also associated with another rare pathology of anemia called Zieve syndrome, which is thought to be a variant of spur cell anemia. ${ }^{[11]}$ Alcohol abusers after binge drinking can develop Zieve syndrome, which comprises of a triad of hemolysis, cholestatic jaundice, and hyperlipidemia. Spur cell appearance on a peripheral blood smear is absent in Zieve syndrome, and patients will typically recover quickly with alcohol abstinence. In contrast, patients with spur cell anemia require urgent orthotopic liver transplantation for survival. ${ }^{[3,12]}$ Thus, early diagnosis is crucial.

\section{CONFLiCTS OF INTEREST Disclosure}

The authors have declared no conflicts of interest.

\section{REFERENCES}

[1] Douglass, C.C., M.S. McCall, and E.P. Frenel, The acanthocyte in cirrhosis with hemolytic anemia. Ann Intern Med. 1968; 68(2): 390-7. PMid:5713921. https://doi.org/10.7326/0003-4819-68-2 $-390$

[2] Keyserling K, Koprowski S. Spur-Cell Anemia. N Engl J Med. 2018; 379(8): 774. PMid:30134135. https://doi .org/10.1056/NEJM i cm1714572

[3] Smith JA, Lonergan ET, Sterling K. Spur-Cell Anemia: Hemolytic Anemia with Red Cells Resembling Acanthocytes in Alcoholic Cirrhosis. N Engl J Med. 1964; 271: 396-8. PMid:14164657. https : //doi.org/10.1056/NEJM196408202710804

[4] Murphy CH. Spur cell hemolytic anemia in liver failure. Transfusion. 2016; 56(4): 787-8. PMid:27079310. https ://doi.org/10.111 $1 / \operatorname{trf} .13407$

[5] Saibara T. Spur cells and acanthocytes in liver diseases. Hepatol Res. 2007; 37(6): 402-4. PMid:17539813. https ://doi .org/10.111 $1 / j .1872-034$ X.2007.00110.x

[6] Marks EI, Ollila TA. Acanthocytosis causing chronic hemolysis in a patient with advanced cirrhosis. Blood. 2019; 133(13):
1518. PMid:30923109. https://doi.org/10.1182/blood-201 9-01-897892

[7] Marshall AT, Waxman I. Image of the month. Spur cell anemia. Gastroenterology. 1997; 112(2): 326-673. PMid:9024285. https: //doi.org/10.1053/gast.1997.v112.agast970326

[8] Sugimoto S. Spur cell anemia associated with alcoholic cirrhosis. Intern Med. 2013; 52(24): 2831. PMid:24334595. https: //doi.org/10.2169/internalmedicine.52.1335

[9] Malik P. Spur cell anemia in alcoholic cirrhosis: cure by orthotopic liver transplantation and recurrence after liver graft failure. Int Surg. 2002; 87(4): 201-4.

[10] Partain DK. Spur cell anemia in the setting of progressive liver allograft failure. Am J Hematol. 2016; 91(10): 1061. PMid:26874796. https://doi.org/10.1002/ajh. 24331

[11] Liu MX. Hemolytic anemia in alcoholic liver disease: Zieve syndrome: A case report and literature review. Medicine (Baltimore). 2017; 96(47): e8742. PMid:29381966. https ://doi .org/10.109 7/MD. 0000000000008742

[12] Shah R, Patel A, John S. Spur cell anemia in end-stage liver disease: a zebra! Am J Emerg Med. 2014; 32(8): 944 e3-4. PMid:24581882. https://doi.org/10.1016/j.ajem.2014.01.027 